\title{
Study of Separately and in Combination Impacts of Zinc- Oxide and Multiwall-Carbon-Nanotube on the Freshwater Prawn (Macrobrachium Nipponense De Haan, 1849), in Laboratory Condition
}

\author{
Kamran Rezaei Tavabe ( $\nabla$ krtavabe@ut.ac.ir ) \\ Tehran University: University of Tehran https://orcid.org/0000-0003-0667-2775 \\ Bahareh Samadi Kuchaksaraei \\ Tehran University: University of Tehran
}

Sina Javanmardi

Tehran University: University of Tehran

Divya Sivaji

National Center for Vector-Borne Diseases

\section{Research Article}

Keywords: Biomarker, Carbon nanotubes (CNTs), Bio-indicator, Bio-monitor, Enzyme activity, Detoxification.

Posted Date: June 9th, 2021

DOI: https://doi.org/10.21203/rs.3.rs-590632/v1

License: (c) (i) This work is licensed under a Creative Commons Attribution 4.0 International License. Read Full License 


\section{Abstract}

Nanomaterials (NMs) have settling behavior and accumulate in the benthic area of the aquatic ecosystems. Because of deposit-omnivorous feeding behavior of decapod crustaceans, these order species are appropriate biological models to assay NMs eco-toxicological effects. The present study evaluated the toxicity effects of ZnO and MWCNTs nanomaterials as separately and in combination on antioxidant enzymes activities, $\mathrm{CHH}$ hormone, hematology, reproductive performance, and hepatopancreas lesions of the Macrobrachium nipponense. The study was carried out in two stages. At the first experiment, concentrations of $\operatorname{ZnO}(0,1,10,30,50 \mathrm{mg} / \mathrm{L})$ and MWCNTs $(0,5,10,15,20 \mathrm{mg} / \mathrm{L})$ were assayed then at the second experiment, two higher concentrations of the NMs in the first stage were compared in combined treatments. The experimental tanks (500 I RAS system) were stocked 12 females and four males during 60 days. Both NMs showed dose-dependent toxicity effects on $M$. nipponense reproductive parameters and especially eggs fertilization rate. Also, the results depicted that by increasing the NMs concentrations, inter-molt and inter-spawn periods were postponed so that in $50 \mathrm{ppm} \mathrm{ZnO}$ and 15 and 50 ppm MWCNTs treatments reproduction activities were stopped. The findings showed that $\mathrm{CHH}$ hormone release and superoxide dismutase (SOD) enzyme activity have direct relations to the NMs levels independently and in combination. Also, the results demonstrated that large granular hemocyte (LGH) deal with NMs detoxification in decapod crustacean's hemolymph mainly. The NMs did not show any effect on ALT and AST enzymes activities in muscle tissue independently, but the NMs combined effects on these enzymes activities were significant. Also, the NMs caused hepatocyte enlargement, melanization, apoptosis, and necrosis damages in the hepatopancreas. The findings showed that $\mathrm{ZnO}$ and MWCNTs NMs have strongly adverse effects on M. nipponense, and this species is an appropriate bio-indicator and bio-monitor organism for NMs contaminations in the freshwater aquatic environments.

\section{Highlights}

- The NMs showed adverse effects on M. nipponense reproductive performances.

- The NMs showed dose-dependent toxicity to M. nipponense independently and in combination.

- $\mathrm{cHH}$ hormone release has direct relations to concentrations of both NMs.

- Antioxidant enzyme activities have direct relations to concentrations of both NMs.

\section{Introduction}

Nowadays, nanomaterials (NMs) are extensively applied for different applications and industries. Zinc oxide (ZnO) and carbon nanotubes (CNTs) are common synthetic NMs that are widely used in several fields and industries (Siddiqi et al. 2018). ZnO NMs are metal oxide NMs and because of their physic-chemical properties, are applied in various industries (Qu et al. 2013; Jiang et al. 2018; Siddiqi et al. 2018; Nezhadheydari et al. 2019). On the other hand, MWCNTs NMs are carbon-made nanostructure tubes that have been used in the pharmaceutical industry because of their high surface capacity to absorb or conjugate with different medicines (He et al. 2013). In the past years, with increasing human knowledge and ability to produce and use these NMs, they have received considerable attention to their potential hazards and toxicities on the environment and aquatic organisms (Wardak et al. 2008; Azam et al. 2012, Morozesk et al. 2018).

NMs are relatively new materials, and they can cause harmful impacts on different bio-organisms and ecosystems because animal cells can receive them because of their size and dimension. Zheng et al. (2009) evaluated harmful effects of $\mathrm{ZnO}$ NMs in mice and showed that these NMs caused damage in various tissues. The same results were obtained by Wang et al. (2008) and depicted that tissue damages caused by ZnO NMs as dose-dependent. Also, in biological models, exposure to CNTs caused genotoxicity and even cells and tissue intense damages during long term exposure via high biopersistence in the cells (Kobayashi et al. 2017). ZnO NMs release into the aquatic environments through various wastewaters and cause harmful impacts on aquatic animals (Rajput et al. 2018; Wu et al. 2019). Also, CNTs NMs are 
harmful to aquatic animals and invertebrates and can cause cytotoxicity in these bio-organisms (Jackson et al. 2013). These NMs toxicity effects on different freshwater environment species have been confirmed by Mwangi et al. (2012).

Decapod crustaceans, because of the relatively long lifecycle, omnivorous feeding behavior, wide distribution, and simple anatomy, are appropriate bio-monitors of various NMs pollutants in aquatic environments (Rezaei Tavabe et al. 2019; Chen et al. 2020; Zhang et al. 2020). Freshwater prawn species, Macrobrachium nipponense, is native of the West Pacific countries to East Asia in the subtropical and temperate zones (Cai and $\mathrm{Ng} 2002$ ) and it has been moved to Asian eastern countries (Cai and Shokita 2006) and middle east countries such as Iran and Iraq (De Grave and Ghane 2006). This species is resistant to environmental variations and can breed exclusively in freshwater (De Grave and Ghane 2006). Freshwater aquatic animals can be used as bio-indicator and bio-monitor to assay different pollutants individual and ecosystem effects (Yang 2014). NMs have settling behavior and accumulate in the benthic area of the aquatic ecosystems, and because of omnivorous-deposit feeding behavior of decapod crustaceans, these order species are appropriate biological models to assay NMs eco-toxicological effects. So, the main objective of this study is evaluation of toxicity effects of $\mathrm{ZnO}$ and MWCNTs NMs as separately and in combination on reproductive performance, antioxidant and metabolizing enzyme activities, $\mathrm{CHH}$ hormone, hematology, and hepatopancreas lesions of the M. nipponense.

\section{Materials And Methodology}

\section{Nanomaterials}

The required NMs, including ZnO and MWCNTs, were prepared from Sigma-Aldrich Co. (USA), and SEM photos of the obtained NMs were taken, and the mean dimension diameter of ZnO and MWCNTs NMs were found about 50 and $38 \mathrm{~nm}$, respectively (Fig. 1).

\section{Studied animals}

Prawns $(n=700)$ for this study were caught from the Anzali wetland basin rivers, located in the Guilan province, Iran. The average prawn weight was $3 \pm 0.5 \mathrm{gr}$. Prawns were transferred to the University of Tehran Aquaculture Department laboratory and stocked in 5000-I tank for adaptation period (10 days). In this tank, water quality parameters were according to Rafiee et al. (2015) and Rezaei Tavabe et al. (2015b) recommendations.

\section{Experimental set up}

Research was carried out in two experiments: In the first experiment, ZnO concentrations $(0,1,10,30,50 \mathrm{mg} / \mathrm{L})$ and $\operatorname{MWCNT}(0,5,10,15,20 \mathrm{mg} / \mathrm{L})$ were independently assayed and at the second experiment, interactions of two higher concentrations of the NMs in the first stage were compared on the M. rosenbergii. Each experiment unit (500 I RAS system) was stocked 12 brood-females and four brood-males during 60 days research period in triplicate. During the study, the photoperiod and temperature were set at $12 \mathrm{~h}$ light and $28 \pm 1^{\circ} \mathrm{C}$ respectively, based on Rezaei Tavabe et al. (2015a). The prawns were fed twice a day with a formulated commercial shrimp feed.

\section{Evaluation parameters}

\section{- Prawns reproductive and growth parameters}

Weight gain (WG), survival rate, inter-spawn and inter-molt periods, total fecundity, egg fertilization rate, eggs dry weight, and ESI (egg clutch somatic index) indices were measured at the end of experiments as growth and reproductive performances. ESI, total fecundity, and WG parameters were calculated in accordance with Rafiee et al. (2015).

\section{- Hematology assay}


SGH (Small granular hemocyte) and LGH (large granular hemocyte) were determined at the end of the experiment period by monitored light microscope as hematological assay parameters. Hemolymph sampling and hemocytes counting carried out based on Leigh and Antoinette (1997) protocol.

\section{- Crustacean's Hyperglycemic hormone (CHH) measurement}

Hemolymph CHH level was measured based on Levenson et al. (1999) method. According to this method, the hemolymph samples in each tube were mixed 1:1 with $\mathrm{NaHCO} \otimes$ buffer solution. Then, after washing with a standard solution (10 $\mathrm{mM} / \mathrm{I}$ PBS, pH 7.4 and $0.1 \%$ Tween 20 ), the dishes were blocked by $100 \mu \mathrm{l}$ of blocking buffer solution (10 mM/I PBS, $0.1 \%$ Tween 20, 2\% BSA) for two hours and then incubated with the anti-CHH solution (dilution 1:10 000 in blocking buffer) for two hours at room temperature. The dishes were washed and incubated with the secondary specific antibody, anti-rabbit IgG peroxidase (Sigma Co. A4914), for two hours at room temperature. The dishes were washed again, and $100 \mu$ l of Tetramethylbenzidine (TMB) ELISA substrates were added into each tube to initiate the enzyme reaction for 10-30 min at $37^{\circ} \mathrm{C}$. Then, by adding two $\mathrm{M} / \mathrm{I}$ Sulfuric acid, the enzyme reaction was blocked and was detected at $450 \mathrm{~nm}$ on ELISAreader device (Cyberlab Inc., USA).

\section{- Antioxidant and metabolizing enzymes assay}

At the end of the experiment period, three prawns from each treatment were sampled, and their muscle tissue samples were removed and rinsed by standard solution, according to Jiang et al. (2014). After that, about $0.1 \mathrm{~g}$ of rinsed samples was homogenized, and half of the homogenate solution was centrifuged at $860 \mathrm{xg}$ for $10 \mathrm{~min}$ at $4^{\circ} \mathrm{C}$. The supernatant was used for activity assays of the most important metabolizing enzymes, including AST and ALT. Also, SOD enzyme activity as an antioxidant enzyme was measure according to the method used by Du et al. (2019).

\section{- Histological analysis}

At the end of the research period, tissue samples from the prawn hepatopancreas were taken and fixed with $10 \%$ formalin. After 24 hours, the samples were rinsed by phosphate buffer saline. After dehydration processing, and paraffinization under standard protocols, $5 \mu \mathrm{m}$ sections were prepared by microtome and then stained by H\&E method and analyzed by light monitored microscope.

\section{Data procedure}

The obtained data of the first experiment were analyzed by one-way ANOVA in SPSS software version 24 . In the $2^{\text {nd }}$ experiment, the interactions of both NMs on the studied parameters were analyzed by two-way ANOVA using the same software.

\section{Results}

\section{Growth and reproductive performances}

Experimental tanks water physicochemical parameters including temperature $\left(28 \pm 1^{\circ} \mathrm{C}\right), \mathrm{pH}(7.6), \mathrm{DO}(6 \pm 1 \mathrm{mg} / \mathrm{l}), \mathrm{NH}_{3}$ $(<0.2 \mathrm{mg} / \mathrm{l})$ and $\mathrm{NO}_{2}(<0.1 \mathrm{mg} / \mathrm{l})$ were routinely recorded. Table 1 shows weight gain (WG), survival, and some reproductive parameter records. By increasing the concentrations of both NMs in the treatments, eggs fertilization rate, eggs dry weight, HIS, WG, and survival rate were decreased significantly. Also, by increasing the concentrations, inter-molt and inter-spawn periods were prolonged so that in the $50 \mathrm{mg} / \mathrm{L} \mathrm{ZnO}, 15$ and $50 \mathrm{mg} / \mathrm{L} \mathrm{MWCNT}$ treatments, reproductive activities were stopped. Even though fecundity among the treatments was the same, but the least ESI for ZnO and MWCNT NMs was recorded in the 30 and $10 \mathrm{mg} / \mathrm{L}$ concentrations, respectively.

\section{CHH hormone release}


In the crustaceans, $\mathrm{CHH}$ is known as the stress-metabolism hormone. According to the results, in the prawns, MWCNT

caused more stress and metabolism activities than ZnO. Interestingly, there were no significant differences in the 1 and 10 $\mathrm{mg} / \mathrm{L}$ treatments of $\mathrm{ZnO}$ compared to the control treatment (Fig. 2).

\section{Antioxidant and metabolizing enzymes activity}

The results depicted that SOD activity in hepatopancreas organ of $M$. nipponense in response to MWCNT challenge is significantly sharper than ZnO. According to the results, only the $50 \mathrm{mg} / \mathrm{L}$ treatment of $\mathrm{ZnO}$ showed a significant

difference compared to the control treatment, while all MWCNT trial treatments showed significant differences with each other and the control treatment (Fig. 3). However, the results about two other transaminase enzymes activities, including ALT and AST in muscle tissue of M. nipponense, hadn't any statistical differences among the treatments in both NMs treatments (Table 2).

\section{Hematology factors}

Small and large hemocytes (SGH and LGH) are the main hemato-immunity factors in challenge with stressors in decapod crustacean's hemolymph. The results indicated that by increasing the levels of both NMs in the treatments, SGH and LGH values of M. nipponense hemolymph were decreased and increased, respectively (Fig. 4).

\section{Interaction effects of combined ZnO/CNT NMs on M. nipponense}

At the second stage, to investigate the interaction of toxicological effects of the NMs on the M. nipponense, combinations of two higher concentrations in the first stage were studied on different physiological, immunity, and histopathological factors of the prawns.

\section{- $\mathrm{CHH}$ hormone release}

Fig.5 presents the combined effects of the NMs on the CHH stress-metabolism hormone. The combined 30/20 and 50/20 $\mathrm{mg} / \mathrm{L}$ treatments caused the highest hormone secretion among the treatments. Also, significant differences among the treatments of the hormone secretion are due to the interactions of both NMs to each other $(P<0.05)$.

\section{- Antioxidant and metabolizing enzymes activity}

Based on the findings, combined treatments indicated significant differences in the SOD enzyme activity of $M$. nipponense hepatopancreas compared to the control treatment, and the 5/20 combined treatment caused the highest SOD enzyme activity (157 u/g protein) (Fig. 6). Although in the first stage, there were not any significant differences among the treatments on ALT and AST enzymes activities, at this stage, these enzymes activities among the combined treatments were statically different, and in ALT enzyme activity, the differences among the treatments were due to the both separately and in combination effects of the NMs. In the AST enzyme activity, the ZnO factor effect was not significant $(P>0.05)$, but its interaction effect with the MWCNT factor on this enzyme activity was significant (Table 3 ).

\section{- Hematology factors}

All the combined treatments showed significant differences with the control treatments in both SGH and LGH hematoimmunity factors. For LGH, both NMs had independently and interaction effects, but for SGH, the NMs showed alone affects, but their interaction was not significant (Table 4).

\section{- Hepatopancreas histopathology}

Histopathology of hepatopancreas tissue sections in the crustaceans is one of the best reliable methods to assess cellular damages. Fig. 7 shows normal hepatocytes with the normal lumen in the control treatment (a), while in the 
combined 30/15 mg/L treatment, (b) the lumens have been dilated. At the other combined treatments, the hepatocyte's damages such as enlargement, melanization, apoptosis, and even tissue necrosis are apparent.

\section{Discussion}

Nano-ecotoxicology concentrates on the harmful effects of NMs on organisms and their ecosystems and uncovers harmful mechanisms and bioavailability of NMs in the organisms (Yung et al. 2014). Outputs of this study depicted that M. nipponense metabolism enzymes activities, hemato-immunity factors, $\mathrm{CHH}$ metabolizing hormone, hepatopancreas tissue histopathology, survival rate, reproductive indices, growth, and reproductive performances were strongly affected by the toxicity of ZnO and MWCNT NMs. NMs characteristics, including surface area, surface coating, surface charge, material size, bio-accumulation, and dissolution, may affect cell uptake and distribution in tissues of the aquatic organism (Zhao et al. 2013; Walters et al. 2016). As soon as NMs enter the body of bio-organisms, they cause oxidative stress and intracellular calcium homeostasis perturbation, and subsequent reactions result in cell damage, and deregulation of the cell cycle (Huang et al. 2017). Bio-accumulation and cell damages of NMs in aquatic organisms are depending on both absorption and elimination of the NMs out of the organism's body (Walters et al. 2016). Exbrayat et al. (2015) reported that when the NMs exposition for crustaceans is chronic, growth and reproduction are decreased, and then the toxicological impacts happen in their cells and tissues. In crustacean organisms, the exposure pathways are mainly via feeding behavior and adsorption to surface such as the gills and NMs may also diffuse into the hemolymph and accumulate in different organs (Walters et al. 2016).

The both ZnO and MWCNT NMs indicated dose-dependent harmful effects to $M$. nipponense separately and in combination. By increasing ZnO and MWCNT levels, CHH stress-metabolism hormone and superoxide dismutase (SOD) enzyme activity were increased. Lorenzon et al. (2004) indicated that $\mathrm{CHH}$ hormone excretion in decapod crustaceans has direct related to their exposure to stressors. The stressors induce hyperglycemia and glucose release from the hepatopancreas storage cells by secretion of $\mathrm{CHH}$ hormone from the X-Organ (Santos and Keller 1993) to provide energy to deal with stressors. Stressors cause oxidant stress in the crustaceans; oxidant stress is an imbalance between produced ROS and the cellular abilities to eliminate these productions that may be a result of increased ROS production, a decrease in the cellular defense process, or a combination of both of them. SOD is an antioxidant enzyme that catalyzes the produced ROS radicals into safe molecules such as oxygen and hydrogen peroxide, and the enzyme activity is an appropriate biomarker for stressors in aquatic organisms (Walters et al. 2016). Chang et al. (2012) showed that ZnO NMs are highly reactive agents and increase ROS production and cause genotoxicity even at low concentrations in aquatic organisms. Lukhele et al. (2015) confirmed the same toxicity effects of MWCNT NMs on three aquatic animals, including Pseudokirchneriella subcapitata, Daphnia pulex, and Poecilia reticulate. In addition to $\mathrm{CHH}$ hormone release and SOD enzyme activity, our results showed that in combination, effects of ZnO and MWCNT NMs cause ALT and AST enzymes activities on the M. nipponense muscle tissue while the NMs hadn't shown any impacts on the enzymes as independently at the first stage of the present study. Amjad et al. (2018) showed that NMs increased ALT and AST enzyme activities in a dose-dependent manner in the Channa punctatus fish. Results of the present study not only confirm the past reports, but also emphasize that the combined effects of NMs are more toxicant to M. nipponense as a freshwater decapod crustacean.

Aquatic invertebrate organisms have an efficient innate immune system, including hematological and cellular defense reactions. There are mechanisms that the hematological and cellular reactions are well coordinated between each other (Perez and Fontanetti 2011). Hemolymph cells or hemocytes (including hyaline, LGH, and SGH) circulate freely through the invertebrate's body and recognize foreign factors to the bio-organism and after identifying the foreign factor with different mechanisms eliminate it or minimize its effects (Lavine and Strand 2002; Falleiros et al. 2003), it was also indicated agglomerations of hemocytes around the stressor factor in a type of trapping mechanism (Jiravanichpaisal et al. 2006). Based on the hematological findings, by increasing ZnO and MWCNT levels, LGH hemocyte value increased, 
and conversely, SGH hemocyte decreased. It is probable that in the decapod challenge to NMs, mainly LGH hemocyte detoxifies by different above-mentioned mechanisms and its value increase in the hemolymph. Since hemocyte counts in hemolymph are relative, LGH increment causes a relative reduction of SGH hemocyte.

The crustacean hepatopancreas has various functions, including absorption, detoxification, nutrients storage, and vitellogenesis for ovarian development. There are four hepatopancreatic cell kinds in decapod crustaceans, E (vitelline precursor), R (storage), $\mathrm{F}$ (fibrillary cells for absorption), and B (blister: metabolizing and detoxification) cells (Vitorino et al. 2018). The hepatopancreas is the main detoxification tissue and has a vital function in health, growth, survival and it is commonly used as a monitoring organ for the general evaluation of the organism's health conditions (Hu and Leung 2007). In the present study, by increasing ZnO and MWCNT concentrations in the combined treatments, lumens dilatation, hepatocytes enlargement, melanization, apoptosis, and even tissue necrosis appeared in the $M$. nipponense hepatopancreas tissue. The histological changes may be described to direct toxicological effects of the nano-toxicants on hepatocytes because it is the main site of elimination and detoxification and hence a sink for potential toxicants metabolites (Abd El-Atti et al. 2019). In the hepatopancreas tissue, the most prominent pathological lesions are lumen destruction and hepatocyte enlargement. Koehler et al. (2008) showed that in combination NMs caused severe tissue damages in the blue mussel (Mytilus edulis) hepatopancreas and gills tissues. The results depicted that hepatopancreas histopathology of decapod crustaceans such as Freshwater prawn (M. nipponense) is an appropriate biomarker to indicate NMs contamination and monitoring in the freshwater ecosystems.

\section{Conclusion}

Both ZnO and MWCNT NMs showed dose-dependent toxicities to the freshwater prawn (M. nipponense) independently and in combination. This study shows the potential impacts of these NMs exposure to M. nipponense reproductive behavior and performance, hematology factors, antioxidant and metabolizing enzyme activities, $\mathrm{CHH}$ hormone release, and hepatopancreas histopathology. Also, the results demonstrated that in the hemato-immunity system, mainly LGH hemocyte detoxifies NMs by different mechanisms in decapod crustacean's hemolymph. On the other hand, the findings indicated that $\mathrm{CHH}$ hormone release and SOD enzyme activity are the most important early processes in decapod crustaceans to deal with nano-toxicants. Also, we depicted that ZnO and MWCNT NMs caused hepatocyte enlargement, melanization, apoptosis, and necrosis damages in M. nipponense hepatopancreas histopathology, and this species is an appropriate bio-indicator and bio-monitor of the NMs contaminations in freshwater aquatic environments.

\section{Declarations}

Acknowledgements We sincerely appreciate the efforts of the Tehran University Aquaculture Department laboratories researchers during the research. Also, special thanks to the Iran National Science Foundation (INSF) for financial support under grant project number 94806669.

Ethics approval At all stages of the experiments, the ethical principles of research for working on animals were performed according to the Ethics Committee for Animal Research, University of Tehran (Committee ID: IR.UT.REC).

Consent to participate All names in authors list have been involved in various stages of experimentation or writing.

Consent to publish All authors agree with submit the paper for publication in the Environmental Science and Pollution Research journal.

Authors contributions Kamran Rezaei Tavabe: Funding acquisition, Conceptualization, review \& editing. Bahareh, Samadi Kuchaksaraei: Investigation, Writing original draft. Sina Javanmardi: Investigation, Statistical Analysis, Divya Sivaji: Writing and editing. 
Funding Current research was funded by the Iran National Science Foundation (INSF) under grant number 94806669.

Competing interests The authors are fully satisfied with all stages and there are no conflicts of interests to declare.

Availability of data and materials All data and materials used in the experiment are available and are ready to be provided if needed.

\section{References}

1. Abd El-Atti M, Desouky MMA, Mohamadien A, Said RM (2019) Effects of titanium dioxide nanoparticles on red swamp crayfish, Procambarus clarkii: Bioaccumulation, oxidative stress and histopathological biomarkers. The Egyptian Journal of Aquatic Research 45:11-18.

2. Amjad S, Sharma AK, Serajuddin M (2018) Toxicity assessment of cypermethrin nanoparticles in Channa punctatus: Behavioural response, micronuclei induction and enzyme alteration. Regulatory Toxicology and Pharmacology 100:127-133.

3. Azam A, Ahmed AS, Oves M, Khan MS, Habib SS, Memic A (2012) Antimicrobial activity of metal oxide nanoparticles against Gram-positive and Gram-negative bacteria: a comparative study. International journal of nanomedicine 7:6003-6009.

4. Cai Y, Ng PKL (2002) The freshwater palaemonid prawns (Crustacea: Decapoda: Caridea) of Myanmar. Hydrobiologia 487:59-83.

5. Cai Y, Shokita S (2006) Report on a collection of freshwater shrimps (Crustacea: Decapoda: Caridea) from the Philippines, with descriptions of four new species. Raffl. B. Zool 54:245-270.

6. Chang YN, Zhang M, Xia L, Zhang J, Xing G (2012) The Toxic Effects and Mechanisms of CuO and ZnO Nanoparticles. Materials (Basel) 5:2850-2871.

7. Chen C, Xu C, Qian D, Yu Q, Huang M, Zhou L, Qin JG, Chen L, Li E (2020) Growth and health status of Pacific white shrimp, Litopenaeus vannamei, exposed to chronic water born cobalt. Fish \& Shellfish Immunology 100:137-145.

8. De Grave S, Ghane A (2006) The establishment of the oriental river prawn, Macrobrachium nipponense (de Haan), in Anzali Lagoon, Aquatic Invasions 4:204-208.

9. Du J, Zhu H, Ye M, Ma Y (2019) Macrobrachium rosenbergii Cu/Zn superoxide dismutase (Cu/Zn SOD) expressed in Saccharomyces cerevisiae and evaluation of the immune function to Vibrio parahaemolyticus. Fish \& Shellfish Immunology 90:363-375.

10. Exbrayat JM, Moudilou E, Lapied E (2015) Harmful Effects of Nanoparticles on Animals. Journal of Nanotechnology 8:1-10. https://doi.org/10.1155/2015/861092

11. Falleiros AMF, Bombonato MTS, Gregório EA (2003) Ultrastructural and quantitative studies of hemocytes in the sugarcane borer, Diatraea saccharalis (Lepidoptera: Pyralidae). Brazilian Archives of Biology and Technology 46:287294.

12. He H, Pham-Huy LA, Dramou P, Xiao D, Zuo P, Pham-Huy C (2013) Carbon nanotubes: applications in pharmacy and medicine. Biomed Res Int 2013:578290-578290.

13. Hu KJ, Leung PC (2007) Food digestion by cathepsin $L$ and digestion-related rapid cell differentiation in shrimp hepatopancreas. Comparative Biochemistry and Physiology Part B: Biochemistry and Molecular Biology 146:69-80.

14. Huang YW, Cambre M, Lee HJ (2017) The Toxicity of Nanoparticles Depends on Multiple Molecular and Physicochemical Mechanisms. Int J Mol Sci 18:2702.

15. Jackson P, Jacobsen NR, Baun A, Birkedal R, Kühnel D, Jensen KA, Vogel U, Wallin H (2013) Bioaccumulation and ecotoxicity of carbon nanotubes. Chem Cent J 7:154-154. 
16. Jiang J, Pi J, Cai J (2018) The Advancing of Zinc Oxide Nanoparticles for Biomedical Applications. Bioinorg Chem Appl 2018:1062562-1062562.

17. Jiang Q, Dilixiati A, Zhang W, Li W, Wang Q, Zhao Y, Yang J, Li Z (2014) Effect of nitrite exposure on metabolic response in the freshwater prawn Macrobrachium nipponense, Open Life Sciences pp. 86.

18. Jiravanichpaisal P, Lee BL, Soderhall K (2006) Cell-mediated immunity in arthropods: Hematopoiesis, coagulation, melanization and opsonization. Immunobiology 211:213-236.

19. Kobayashi N, Izumi H, Morimoto Y (2017) Review of toxicity studies of carbon nanotubes. J Occup Health 59:394407.

20. Koehler A, Marx U, Broeg K, Bahns S, Bressling J (2008) Effects of nanoparticles in Mytilus edulis gills and hepatopancreas - A new threat to marine life? Marine Environmental Research 66:12-14.

21. Lavine MD, Strand MR (2002) Insect hemocytes and their role in immunity. Insect Biochemistry and Molecular Biology 32:1295-1309.

22. Leigh O, Antoinette ON (1997) Use of a clinical cell flow cytometer for differential counts of prawn Penaeus monodon haemocytes. Diseases of aquatic organisms 31:147-153.

23. Levenson J, Byrne JH, Eskin A (1999) Levels of serotonin in the hemolymph of aplysia are modulated by light/dark cycles and sensitization training. The Journal of Neuroscience 19:8094-8103.

24. Lorenzon S, Edomi P, Giulianini PG, Mettulio R, Ferrero EA (2004) Variation of crustacean hyperglycemic hormone $(\mathrm{cHH})$ level in the eyestalk and haemolymph of the shrimp Palaemon elegans following stress. Journal of Experimental Biology 207:4205-4213.

25. Lukhele LP, Mamba BB, Musee N, Wepener V (2015) Acute Toxicity of Double-Walled Carbon Nanotubes to Three Aquatic Organisms. Journal of Nanomaterials Special issue Article ID 219074, 19 pages.

https://doi.org/10.1155/2015/219074

26. Morozesk M, Franqui LS, Mansano AS, Martinez DST, Fernandes MN (2018) Interactions of oxidized multiwalled carbon nanotube with cadmium on zebrafish cell line: The influence of two co-exposure protocols on in vitro toxicity tests. Aquatic Toxicology 200:136-147.

27. Mwangi JN, Wang N, Ingersoll CG, Hardesty DK, Brunson EL, Li H, Deng B, 2012. Toxicity of carbon nanotubes to freshwater aquatic invertebrates. Environmental Toxicology and Chemistry 31:1823-1830.

28. Nezhadheydari H, Rezaei Tavabe K, Mirvaghefi A, Heydari A, Frinsko M (2019) Effects of different concentrations of $\mathrm{Fe}_{3} \mathrm{O}_{4} @ \mathrm{ZnO}$ and $\mathrm{Fe}_{3} \mathrm{O}_{4} @ \mathrm{CNT}$ magnetic nanoparticles separately and in combination on aquaculture wastewater treatment. Environmental Technology \& Innovation 15:100414.

29. Perez DG, Fontanetti CS (2011) Hemocitical responses to environmental stress in invertebrates: a review. Environmental Monitoring and Assessment 177:437-447.

30. Qu X, Alvarez PJJ, Li Q (2013) Applications of nanotechnology in water and wastewater treatment. Water Research 47:3931-3946.

31. Rafiee G, Tavabe KR, Frinsko M, Daniels H (2015) Effects of various sodium adsorption ratio (SAR) mediums on larval performance of the freshwater prawn Macrobrachium rosenbergii (de Man). Aquaculture Research 46:725-735.

32. Rajput VD, Minkina TM, Behal A, Sushkova SN, Mandzhieva S, Singh R, Gorovtsov A, Tsitsuashvili VS, Purvis WO, Ghazaryan KA, Movsesyan HS (2018) Effects of zinc-oxide nanoparticles on soil, plants, animals and soil organisms: A review. Environmental Nanotechnology, Monitoring \& Management 9:76-84.

33. Rezaei Tavabe K, Pouryounes Abkenar B, Rafiee G, Frinsko M (2019) Effects of chronic lead and cadmium exposure on the oriental river prawn (Macrobrachium nipponense) in laboratory conditions. Comparative Biochemistry and Physiology Part C: Toxicology \& Pharmacology 221:21-28. 
34. Rezaei Tavabe K, Rafiee G, Frinsko M, Daniels H (2015a) Interactions of different sodium and potassium concentrations on Macrobrachium rosenbergii (de Man) offspring quality parameters. Aquaculture Research 46:2615-2627.

35. Rezaei Tavabe K, Rafiee G, Shoeiry MM, Houshmandi S, Frinsko M, Daniels H (2015b) Effects of Water Hardness and Calcium: Magnesium Ratios on Reproductive Performance and Offspring Quality of Macrobrachium rosenbergii. Journal of the World Aquaculture Society 46:519-530.

36. Santos EA, Keller R (1993) Crustacean hyperglycemic hormone $(\mathrm{CHH})$ and the regulation of carbohydrate metabolism: Current perspectives. Comparative Biochemistry and Physiology Part A: Physiology 106:405-411.

37. Siddiqi KS, ur Rahman A, Tajuddin Husen A (2018) Properties of Zinc Oxide Nanoparticles and Their Activity Against Microbes. Nanoscale Research Letters 13:141.

38. Vitorino HA, Ortega P, Alta RYP, Zanotto FP, Espósito BP (2018) Magnetite nanoparticles coated with oleic acid: accumulation in hepatopancreatic cells of the mangrove crab Ucides cordatus. Environmental Science and Pollution Research 25:35672-35681.

39. Walters C, Pool E, Somerset V (2016) Nanotoxicity in Aquatic Invertebrates. In: Larramendy ML, Soloneski S, Eds, Invertebrates Experimental Models in Toxicity Screening, Intech, Croatia 13-34. https://doi.org/10.5772/61715

40. Wang B, Feng W, Wang M, Wang T, Gu Y, Zhu M, Ouyang H, Shi J, Zhang F, Zhao Y, Chai Z, Wang H, Wang J (2008) Acute toxicological impact of nano- and submicro-scaled zinc oxide powder on healthy adult mice. Journal of Nanoparticle Research 10:263-276.

41. Wardak A, Gorman M, Swami N, Deshpande S (2008) Identification of risks in the life cycle of nanotechnology-based products. Journal of Industrial Ecology 12:435-448.

42. Wu F, Harper BJ, Harper SL (2019) Comparative dissolution, uptake, and toxicity of zinc oxide particles in individual aquatic species and mixed populations. Environmental toxicology and chemistry 38:591-602.

43. Yang JL (2014) Comparative acute toxicity of gallium(III), antimony(III), indium(III), cadmium(II), and copper(II) on freshwater swamp shrimp (Macrobrachium nipponense). Biological Research 47:13.

44. Yung MMN, Mouneyrac C, Leung KMY (2014) Ecotoxicity of Zinc Oxide Nanoparticles in the Marine Environment. in: Bhushan B (Ed.) Encyclopedia of Nanotechnology. Springer Netherlands Dordrecht pp. 1-17.

45. Zhang Y, Li Z, Kholodkevich S, Sharov A, Chen C, Feng Y, Ren N, Sun K (2020) Effects of cadmium on intestinal histology and microbiota in freshwater crayfish (Procambarus clarkii). Chemosphere 242:125105.

46. Zhao X, Wang S, Wu Y, You H, Lv L (2013) Acute ZnO nanoparticles exposure induces developmental toxicity, oxidative stress and DNA damage in embryo-larval zebrafish. Aquatic Toxicology 136-137:49-59.

47. Zheng Y, Li R, Wang Y (2009) In vitro and in vivo biocompatibility studies of ZnO nanoparticles. International Journal of Modern Physics B 23:1566-1571.

\section{Tables}

Table 1. Growth and reproductive parameters (mean \pm SD) of the shrimps at different ZnO and MWCNT treatments during the experiment period. 


\begin{tabular}{|c|c|c|c|c|c|c|c|c|c|c|}
\hline NPs & $\begin{array}{l}\text { Treatments } \\
(\mathrm{mg} / \mathrm{L})\end{array}$ & $\begin{array}{l}\text { Initial } \\
\text { weight } \\
\text { (g) }\end{array}$ & WG\% & $\begin{array}{l}\text { Survival } \\
\text { (\%) }\end{array}$ & $\begin{array}{l}\text { Inter- } \\
\text { molt } \\
\text { period } \\
\text { (days) }\end{array}$ & $\begin{array}{l}\text { Inter- } \\
\text { spawn } \\
\text { period } \\
\text { (days) }\end{array}$ & $\begin{array}{l}\text { Egg } \\
\text { dry } \\
\text { weight } \\
(\mu g)\end{array}$ & $\begin{array}{l}\text { Fecundity } \\
\text { (eggs/ } \\
\text { female) }\end{array}$ & $\begin{array}{l}\text { Eggs } \\
\text { fertilization } \\
\text { (\%) }\end{array}$ & $\begin{array}{l}\text { ESI } \\
(\%)\end{array}$ \\
\hline \multirow{5}{*}{$\mathrm{ZnO}$} & Control & $\begin{array}{l}3 \pm \\
0.5\end{array}$ & $\begin{array}{l}45.2 \\
\pm 2^{a}\end{array}$ & $94 \%$ & $\begin{array}{l}32 \pm 4 \\
a\end{array}$ & $\begin{array}{l}41 \pm 3 \\
a\end{array}$ & $\begin{array}{l}28 \pm 1 \\
a\end{array}$ & $\begin{array}{l}3241 \pm \\
523\end{array}$ & $96 \%$ & $\begin{array}{l}10 \\
\pm 1 \\
a\end{array}$ \\
\hline & 1 & $\begin{array}{l}3 \pm \\
0.5\end{array}$ & $\begin{array}{l}45.3 \\
\pm 2.5 \\
a\end{array}$ & $90 \%$ & $\begin{array}{l}32 \pm 3 \\
a\end{array}$ & $\begin{array}{l}40 \pm 2 \\
a\end{array}$ & $\begin{array}{l}28 \pm 2 \\
a\end{array}$ & $\begin{array}{l}3145 \pm \\
378\end{array}$ & $93 \%$ & $\begin{array}{l}10 \\
\pm 2 \\
a\end{array}$ \\
\hline & 10 & $\begin{array}{l}3 \pm \\
0.5\end{array}$ & $\begin{array}{l}44.0 \\
\pm 2.4 \\
a\end{array}$ & $92 \%$ & $\begin{array}{l}34 \pm 4 \\
a\end{array}$ & $\begin{array}{l}41 \pm 2 \\
\text { a }\end{array}$ & $\begin{array}{l}27 \pm 2 \\
a\end{array}$ & $\begin{array}{l}3230 \pm \\
448\end{array}$ & $81 \%$ & $\begin{array}{l}10 \\
\pm 1 \\
a\end{array}$ \\
\hline & 30 & $\begin{array}{l}3 \pm \\
0.5\end{array}$ & $\begin{array}{l}35.3 \\
\pm 2.6 \\
\mathbf{b}\end{array}$ & $81 \%$ & $\begin{array}{l}37 \pm 5 \\
\text { ab }\end{array}$ & $\begin{array}{l}49 \pm 3 \\
a\end{array}$ & $\begin{array}{l}23 \pm 1 \\
\text { b }\end{array}$ & $\begin{array}{l}3330 \pm \\
376\end{array}$ & $42 \%$ & $\begin{array}{l}8 \pm \\
1^{b}\end{array}$ \\
\hline & 50 & $\begin{array}{l}3 \pm \\
0.5\end{array}$ & $\begin{array}{l}24.7 \\
\pm 1.5 \\
c\end{array}$ & $67 \%$ & $\begin{array}{l}40 \pm 3 \\
b\end{array}$ & - & - & - & & - \\
\hline \multirow{5}{*}{ MWCNT } & Control & $\begin{array}{l}3 \pm \\
0.5\end{array}$ & $\begin{array}{l}45.2 \\
\pm 2^{a}\end{array}$ & $95 \%$ & $\begin{array}{l}32 \pm 1 \\
a\end{array}$ & $\begin{array}{l}40 \pm 2 \\
a\end{array}$ & $\begin{array}{l}28 \pm 2 \\
a\end{array}$ & $\begin{array}{l}3320 \pm \\
514\end{array}$ & $98 \%$ & $\begin{array}{l}10 \\
\pm 1 \\
\mathbf{a}\end{array}$ \\
\hline & 5 & $\begin{array}{l}3 \pm \\
0.5\end{array}$ & $\begin{array}{l}40.3 \\
\pm 1.2 \\
\mathbf{b}\end{array}$ & $87 \%$ & $\begin{array}{l}34 \pm 2 \\
a b\end{array}$ & $\begin{array}{l}46 \pm 1 \\
b\end{array}$ & $\begin{array}{l}26 \pm 1 \\
a b\end{array}$ & $\begin{array}{l}3429 \pm \\
461\end{array}$ & $60 \%$ & $\begin{array}{l}8 \pm \\
2 \\
a b\end{array}$ \\
\hline & 10 & $\begin{array}{l}3 \pm \\
0.5\end{array}$ & $\begin{array}{l}33.1 \\
\pm 1.9 \\
c\end{array}$ & $69 \%$ & $\begin{array}{l}38 \pm 2 \\
\text { b }\end{array}$ & $\begin{array}{l}50 \pm 2 \\
c\end{array}$ & $\begin{array}{l}23 \pm 2 \\
b\end{array}$ & $\begin{array}{l}3251 \pm \\
381\end{array}$ & $27 \%$ & $\begin{array}{l}7 \pm \\
1^{b}\end{array}$ \\
\hline & 15 & $\begin{array}{l}3 \pm \\
0.5\end{array}$ & $\begin{array}{l}25.7 \\
\pm 1.5 \\
\text { d }\end{array}$ & $57 \%$ & $\begin{array}{l}48 \pm 4 \\
c\end{array}$ & - & - & - & & - \\
\hline & 20 & $\begin{array}{l}3 \pm \\
0.5\end{array}$ & $\begin{array}{l}18.8 \\
\pm 1.4 \\
f\end{array}$ & $41 \%$ & $\begin{array}{l}48 \pm 3 \\
c\end{array}$ & - & - & - & & - \\
\hline
\end{tabular}

The comparison is intergroup and means with different superscript letters in same columns of each nanoparticle are significantly different $(P<0.05)$

Table 2. ALT and AST enzymes activity of $M$. nipponense (mean $\pm \mathrm{SD}$ ) at different ZnO and MWCNT treatments (mg/L). There were no significant differences $(P<0.05)$. among the treatments 


\begin{tabular}{|llll|}
\hline Nanoparticles & Treatments $(\mathrm{mg} / \mathrm{L})$ & ALT activity (U/mg protein) & AST activity (U/mg protein) \\
\hline & Control & $215 \pm 21$ & $432 \pm 41$ \\
& 1 & $237 \pm 18$ & $468 \pm 25$ \\
\cline { 2 - 2 } & 10 & $248 \pm 29$ & $440 \pm 35$ \\
& 30 & $224 \pm 23$ & $421 \pm 38$ \\
& 50 & $227 \pm 20$ & $452 \pm 35$ \\
& Control & $223 \pm 29$ & $466 \pm 32$ \\
& 5 & $235 \pm 32$ & $436 \pm 28$ \\
MWCNT & 10 & $208 \pm 27$ & $419 \pm 29$ \\
& 15 & $241 \pm 36$ & $462 \pm 23$ \\
& 20 & $212 \pm 29$ & $450 \pm 27$ \\
\hline
\end{tabular}

Table 3. Effects of ZnO/MWCNT combined treatments on ALT and AST enzymes activity of M. nipponense. Different letters denote significant differences $(P<0.05)$.

\begin{tabular}{|c|c|c|c|c|c|}
\hline $\begin{array}{l}\text { Enzymes } \\
\text { activity }\end{array}$ & $\begin{array}{l}\text { Combined ZnO/MWCNT treatments } \\
(\mathrm{mg} / \mathrm{L})\end{array}$ & $\begin{array}{l}\mathrm{U} / \mathrm{mg} \\
\text { protein }\end{array}$ & $\begin{array}{l}\mathrm{ZnO} \\
\text { factor }\end{array}$ & $\begin{array}{l}\text { MWCNT } \\
\text { factor }\end{array}$ & Interaction \\
\hline \multirow{5}{*}{ ALT } & Control & $211 \pm 7^{a}$ & \multirow{5}{*}{$P=0.037$} & \multirow{5}{*}{$P=0.015$} & \multirow{5}{*}{$P=0.02$} \\
\hline & $30 / 15$ & $245 \pm 11^{b}$ & & & \\
\hline & $30 / 20$ & $259 \pm 14^{b c}$ & & & \\
\hline & $50 / 15$ & $243 \pm 15^{b}$ & & & \\
\hline & $50 / 20$ & $271 \pm 10^{c}$ & & & \\
\hline \multirow{5}{*}{ AST } & Control & $421 \pm 21^{a}$ & \multirow{5}{*}{$P=0.23$} & \multirow{5}{*}{$P=0.028$} & \multirow{5}{*}{$P=0.045$} \\
\hline & $30 / 15$ & $428 \pm 26^{a}$ & & & \\
\hline & $30 / 20$ & $470 \pm 16^{b}$ & & & \\
\hline & $50 / 15$ & $430 \pm 20^{a}$ & & & \\
\hline & $50 / 20$ & $488 \pm 22^{b}$ & & & \\
\hline
\end{tabular}

The comparison is intergroup and means with different superscript letters in same columns of each enzyme are significantly different $(P<0.05)$

Table 4. Effects of ZnO/MWCNT combined treatments on SGH and LGH of M. nipponense. Different letters denote significant differences $(P<0.05)$. 


\begin{tabular}{|c|c|c|c|c|c|}
\hline $\begin{array}{l}\text { Hemato-immunity } \\
\text { factors }\end{array}$ & $\begin{array}{l}\text { Combined ZnO/MWCNT treatments } \\
(\mathrm{mg} / \mathrm{L})\end{array}$ & $\%$ & $\begin{array}{l}\text { ZnO } \\
\text { factor }\end{array}$ & $\begin{array}{l}\text { MWCNT } \\
\text { factor }\end{array}$ & Interaction \\
\hline \multirow{5}{*}{ SGH } & Control & $\begin{array}{l}28 \pm 2 \\
a\end{array}$ & \multirow{5}{*}{$P=0.035$} & \multirow{5}{*}{$P=0.017$} & \multirow{5}{*}{$P=0.411$} \\
\hline & $30 / 15$ & $22 \pm 1$ & & & \\
\hline & $30 / 20$ & $\begin{array}{l}15 \pm 2 \\
c\end{array}$ & & & \\
\hline & $50 / 15$ & $22 \pm 2$ & & & \\
\hline & $50 / 20$ & $\begin{array}{l}15 \pm 2 \\
c\end{array}$ & & & \\
\hline \multirow{5}{*}{ LGH } & Control & $\begin{array}{l}21 \pm 2 \\
a\end{array}$ & \multirow{5}{*}{$P=0.03$} & \multirow{5}{*}{$P=0.005$} & \multirow{5}{*}{$P=0.03$} \\
\hline & $30 / 15$ & $\begin{array}{l}35 \pm 3 \\
b\end{array}$ & & & \\
\hline & $30 / 20$ & $\begin{array}{l}36 \pm 2 \\
b\end{array}$ & & & \\
\hline & $50 / 15$ & $\begin{array}{l}33 \pm 4 \\
b\end{array}$ & & & \\
\hline & $50 / 20$ & $\begin{array}{l}35 \pm 3 \\
\text { b }\end{array}$ & & & \\
\hline
\end{tabular}

The comparison is intergroup and means with different superscript letters in same columns of each hemocyte are significantly different $(P<0.05)$

\section{Figures}



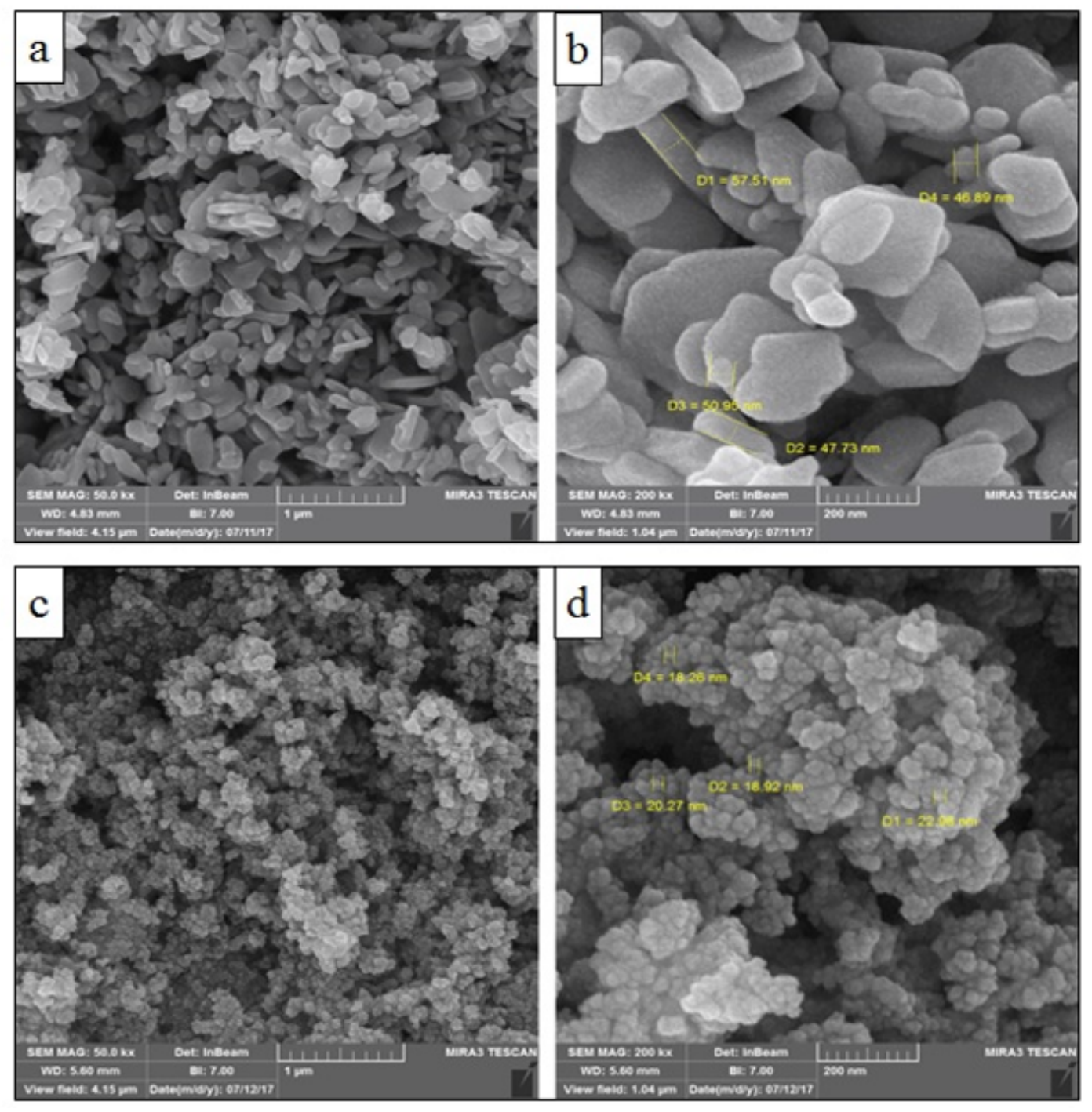

\section{Figure 1}

SEM images of the nanoparticles, ZnO (a and b); MWCNT (c and d).
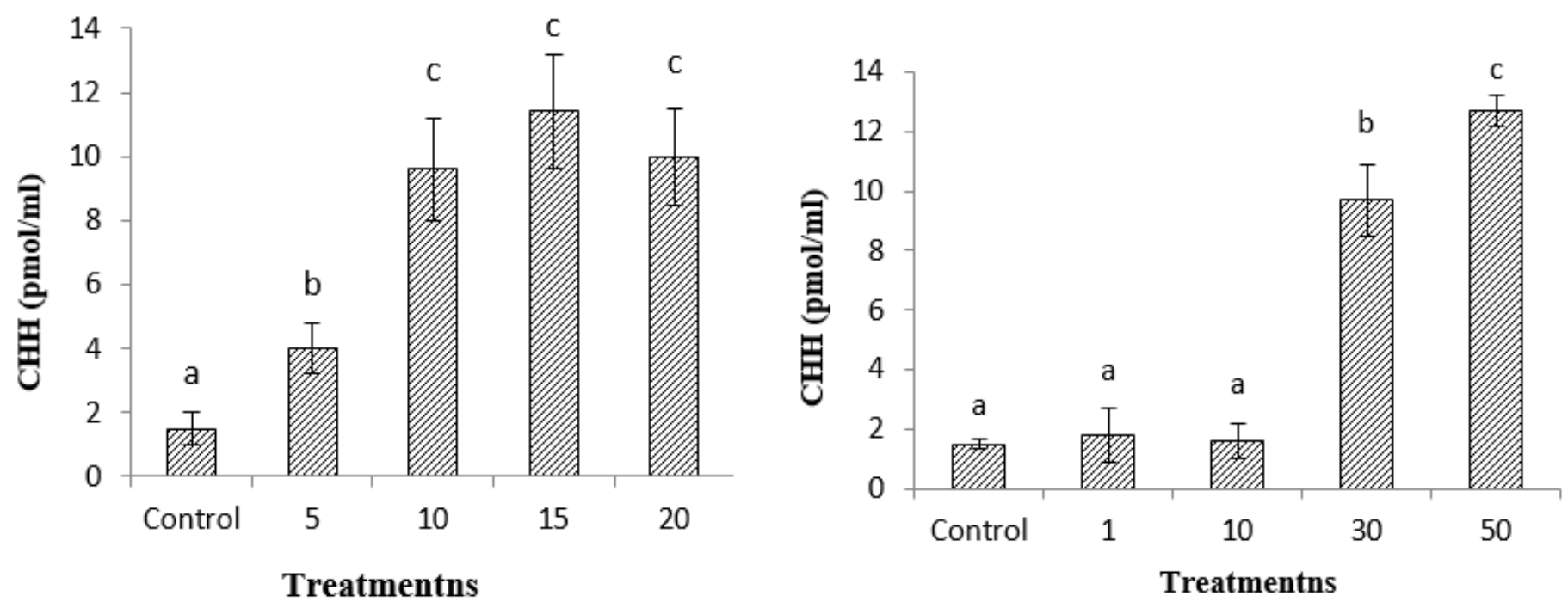
Figure 2

$\mathrm{CHH}$ of M. nipponense (mean $\pm \mathrm{SD}$ ) at different MWCNT (left) and ZnO (right) treatments $(\mathrm{mg} / \mathrm{L})$. The comparison is intergroup and different letters denote significant differences $(P<0.05)$ among the treatments.
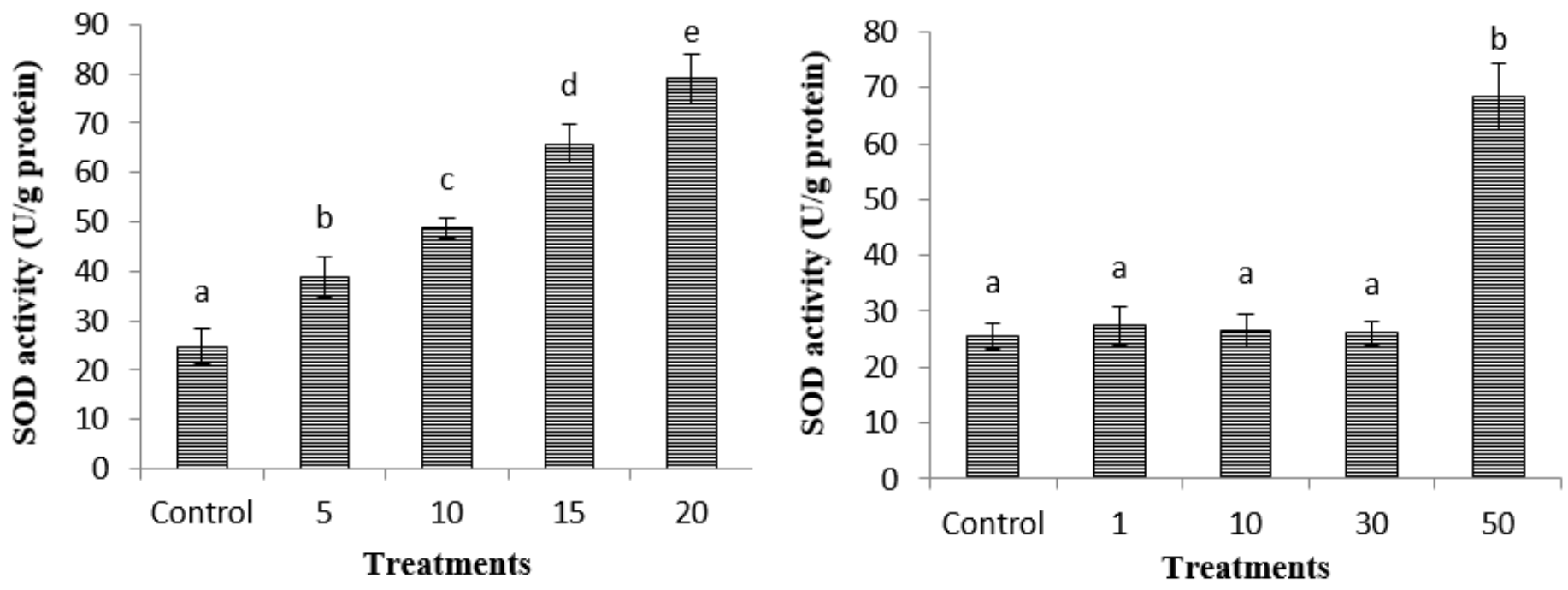

Figure 3

SOD enzyme activity in hepatopancreas tissue of M. nipponense (mean \pm SD) at different MWCNT (left) and ZnO (right) treatments $(\mathrm{mg} / \mathrm{L})$. Different letters denote significant differences $(P<0.05)$ among the treatments.
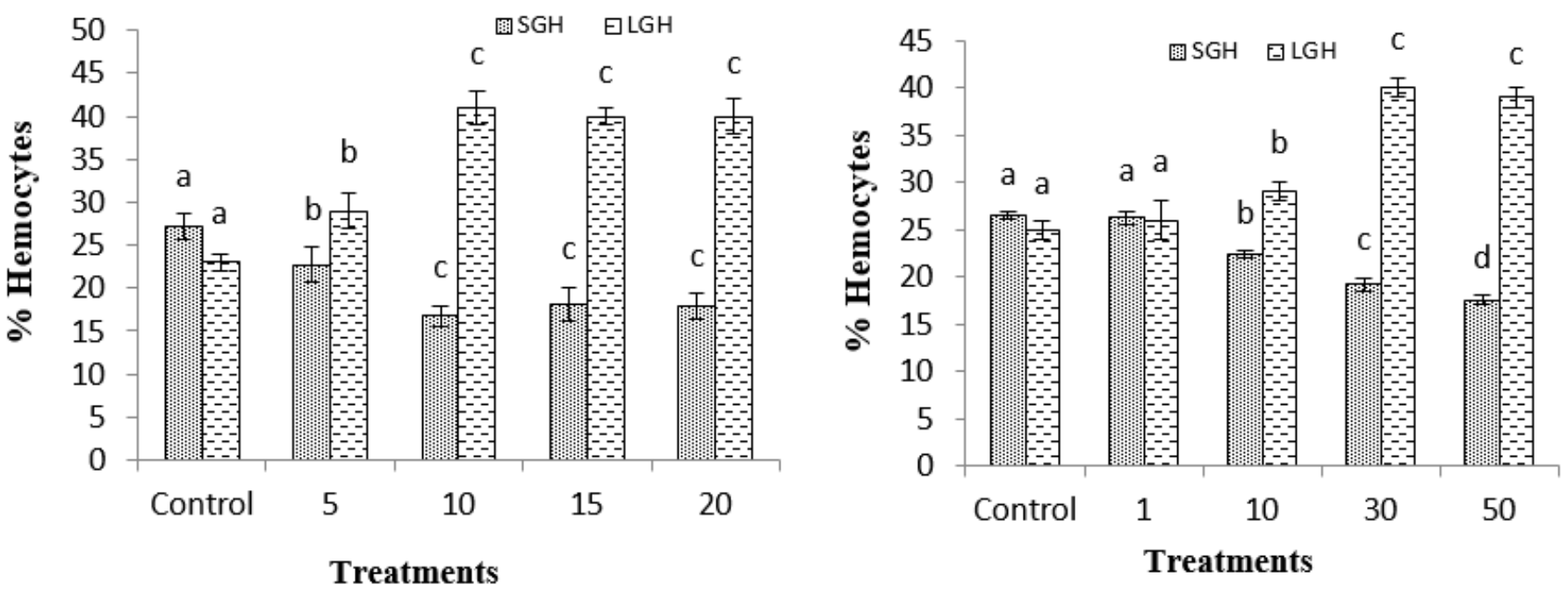

Figure 4

SGH and LGH hemocytes of M. nipponense (mean \pm SD) at different MWCNT (left) and ZnO (right) treatments (mg/L). The comparison is intergroup and different letters denote significant differences $(P<0.05)$ among the treatments. 


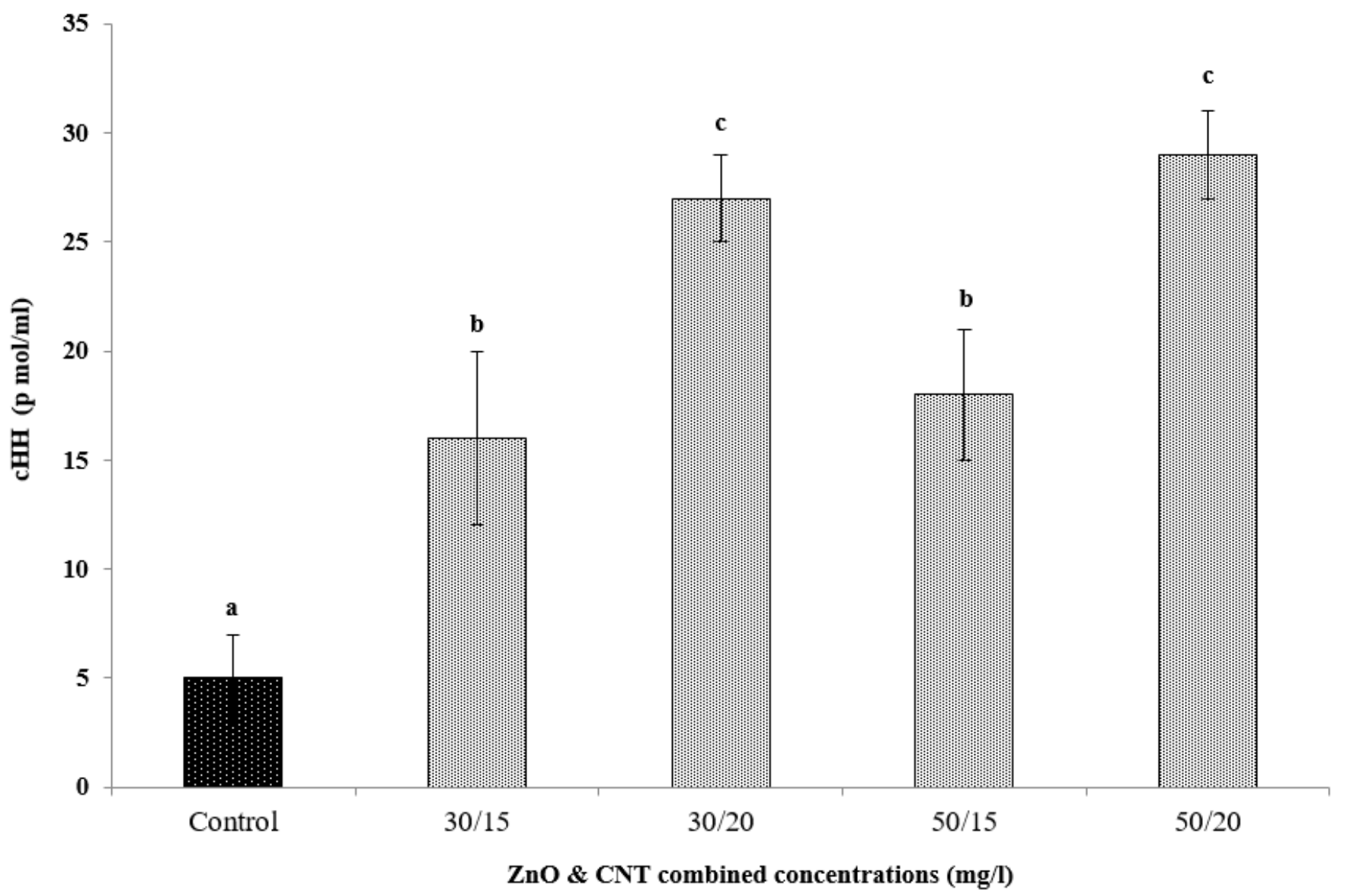

Figure 5

Effects of ZnO/MWCNT combined treatments on SOD enzyme activity of M. nipponense. Different letters denote significant differences $(P<0.05)$. 


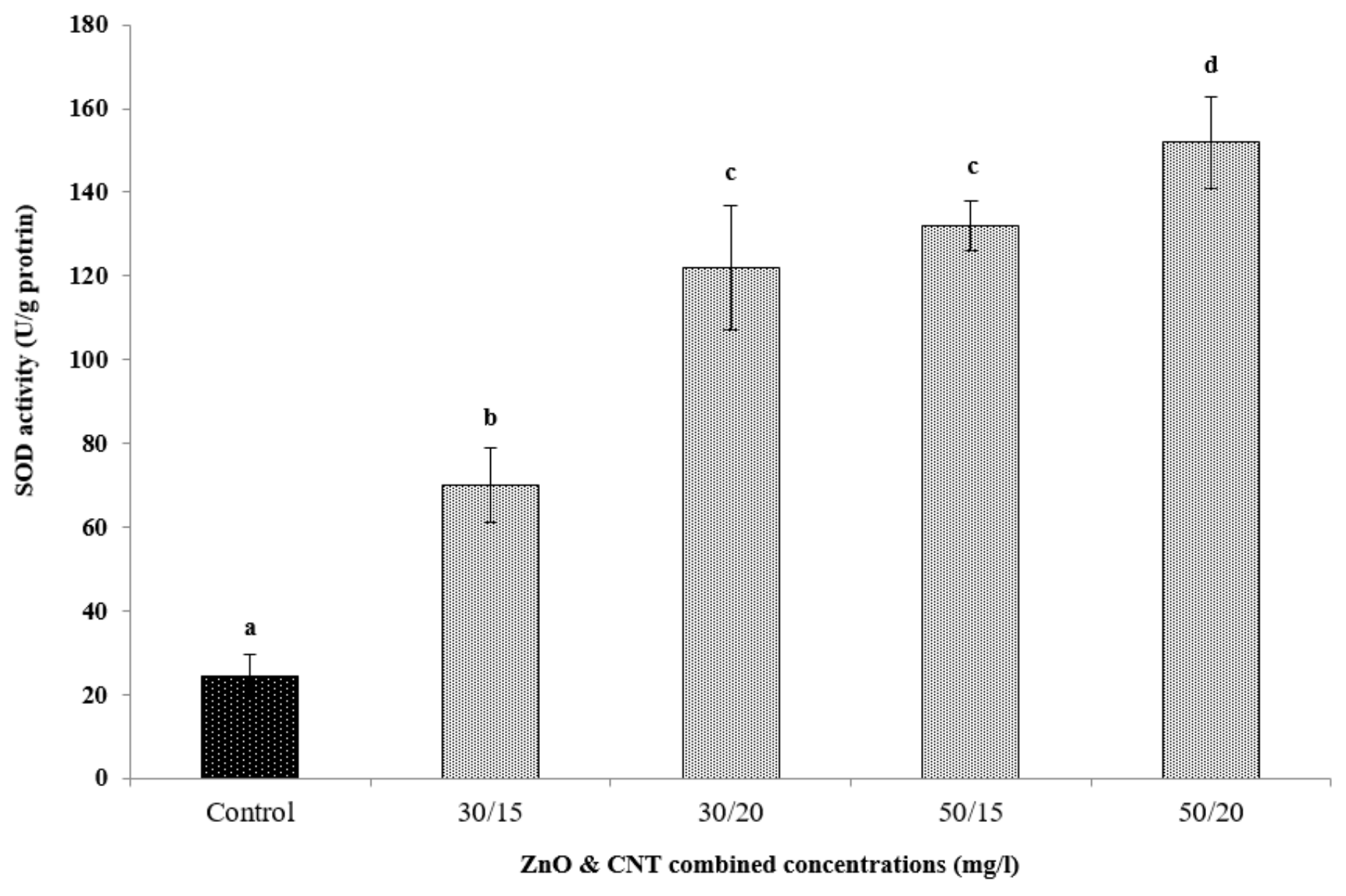

Figure 6

Effects of ZnO/MWCNT combined treatments on SOD enzyme activity of M. nipponense. Different letters denote significant differences $(P<0.05)$. 

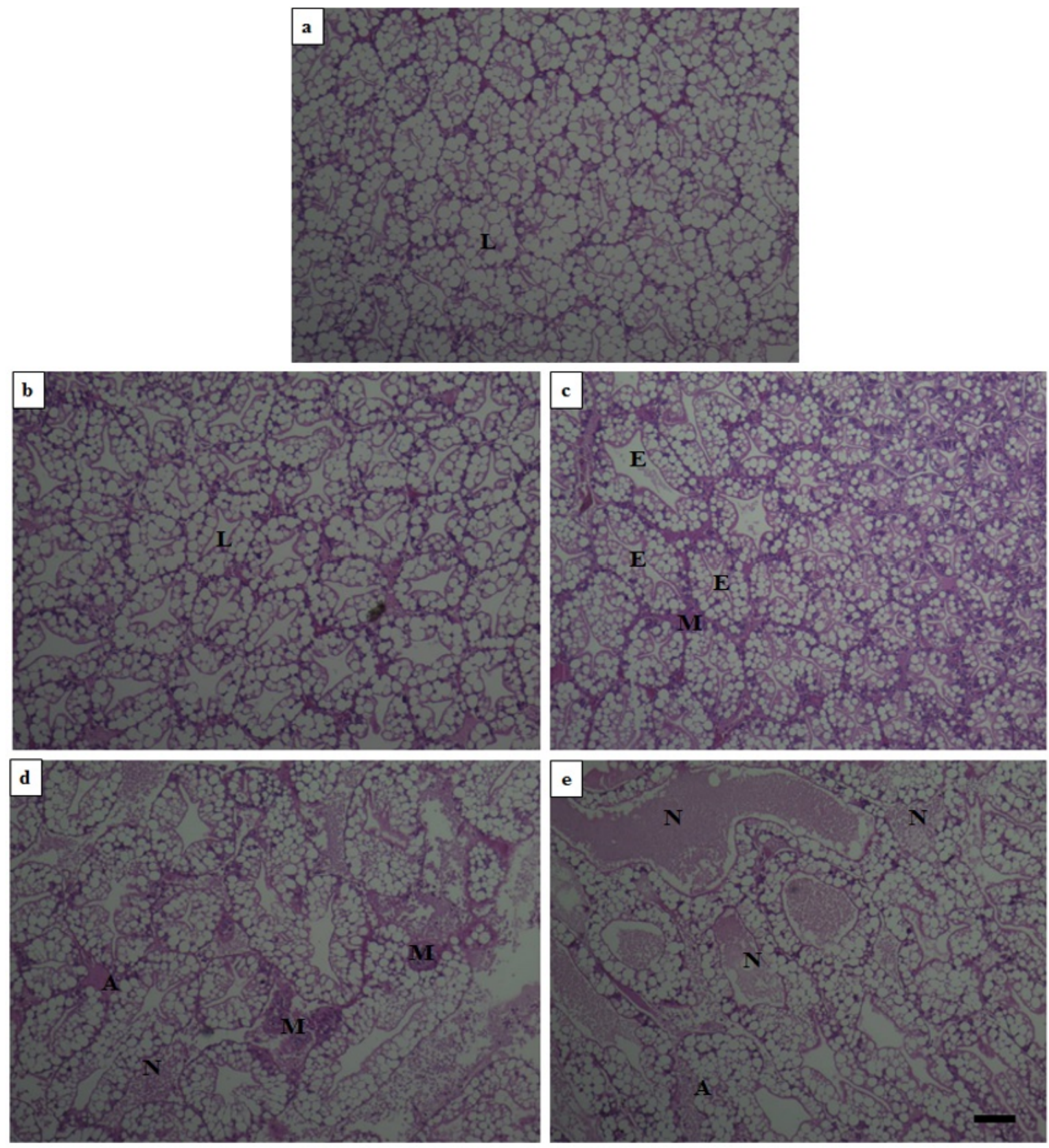

Figure 7

Effects of ZnO/MWCNT combined treatments on hepatopancreas tissue of M. nipponense. a: control treatment b: 30/15 $\mathrm{mg} / \mathrm{L}$ treatment c: $30 / 20 \mathrm{mg} / \mathrm{L}$ treatment d: 50/15 mg/L treatment e: 50/20 mg/L treatment. L: Iumen E: enlargement M: melanization A: appoptosis N: necrosis. Tissue sections were stained with hematoxylin and eosin, and analyzed at $200 \times$ magnification, Scale bar $=0.1 \mathrm{~mm}$. 